\title{
Strategic Aspects of the Diagnosis of Latent Crisis in Organizations
}

\author{
Elena Valerievna Broilo ${ }^{1} \&$ Inessa Georgievna Nazarova ${ }^{1}$ \\ ${ }^{1}$ Ukhta State Technical University, Ukhta, Russian Federation \\ Correspondence: Elena Broilo, Pervomayskaya St. 13, Ukhta, Republic of Komi, 169300, Russian Federation.
}

\author{
Received: March 30, 2015 Accepted: April 20, 2015 Online Published: May 14, 2015 \\ doi:10.5539/res.v7n7p245 URL: http://dx.doi.org/10.5539/res.v7n7p245
}

\begin{abstract}
Studying of the regional tendencies describing economic potential of subjects of business, becomes an integral part of the anti-recessionary program at a level of subjects of the Russian Federation. Studying of the nature of crisis processes, uncertainty of the external and internal environment promotes development of new methods and techniques for detection of the latent stages of crisis. Early diagnostics of the crisis phenomena in economy of region proves that the high level of its social and economic development yet does not provide full economic safety and an opportunity to resist to the threats proceeding from unbalanced structure of economy. Own anti-recessionary programs for the enterprise structures, promoting are necessary to maintenance of steady functioning during crisis.
\end{abstract}

Keywords: crisis process, economic stability, anti-recessionary management of stability, equilibrium condition of the organization, latent stage of crisis, procedure of management of stability, strategy of conservation of stability

\section{Introduction}

In 1990-ies, the economic situation in Russia was that the economic sustainability of many local organizations in the sphere of business was on the verge of acute economic crisis, bankruptcy, and liquidation. Attempts to solve this problem are reflected in many scientific studies and practical developments of domestic experts. At this stage of development of the Russian economy, when the situation in the country is gradually stabilizing, the emphasis has shifted from crisis management resuscitating insolvent institutions towards early diagnosis of economic crisis, mitigate, and overcome their early stages. In this context, it becomes urgent to create a model of economic stability control of a commercial organization, which will actively contribute to the organization of the exit from the economic crisis, and in the future - its transformation into an effective subject of national economic system. These requirements are fully met by innovation-oriented entrepreneurship.

Entrepreneurial activity of Russian companies in the market, their vulnerability to external and internal threats, instability of legislation, leading to a reduction of economic stability, updated the review of approaches and principles of management of the economic crisis and contributed to the transformation methodology for sustainable development of commercial organizations with the use of crisis management, involving different aspects of the organization.

Despite the impressive amount of research on the theoretical and practical aspects of sustainable economic systems, crisis management entrepreneurship organizations, the optimal anti-crisis measures in the transitional economic status has not yet been invited, not enough attention is paid to methods of crisis management in order to maintain economic stability of organizations-business entities (Klimenko, 2008). Crises are not the same, not only for their own reasons, manifestations, and consequences, but also in its essence. As the global and national economies develop, there are all new crises, which could undermine the economic stability of organizations doing business. Given a sufficiently high level of development of this problem by domestic and foreign experts, not enough attention is paid to the methodology of crisis management organization of economic stability in the economic crisis (Anokhin, 2009).

Economic sustainability of a commercial organization reflects its production and economic potential, the degree of balance elements (functional and production units), movement of resources over time, volumes and directions. It determines the position of the subject on the market and, therefore, competitive advantages, and opportunities in the competition (Kaplan \& Norton, 2008). 


\section{Materials and Methods}

Based on our research found that the economic stability of the organization, the leading business is a form of socio-economic equilibrium of the system, which resulted in times of external disturbances manifest integrity of its properties, allowing the complex to form and use of economic and financial resources in each element of the system and to carry out the possibility of expanded reproduction.

Economic sustainability is achieved by a commercial organization at such a state of social and economic relations, in which there is no threat of a critical nature and at the same time retained the ability to complete an economic entity to respond adequately to these threats, manoeuvring financial resources, production program, and technologies (Tatarkin, 2012).

The survival of business organizations that are not directly threatened liquidation due to bankruptcy depends on the level and extent of ongoing preventive anti-crisis work, the ability to fix attention on the so-called "weak signals" about the future, perhaps the crisis changes and find one or the other way out of the crisis.

The existing methods to forecast the economic and financial condition of the organization are based on its financial statements, which have the most informative value for this purpose. Such methods include the analysis of quantitative and based on them discriminant models (Davnis, 2012). Using only the quantitative methods, the analysis does not permit a detailed analysis of the situation, and drawing conclusions on possible ways to stabilize it. The most striking example of imperfection of the used quantitative assessment criteria is the traditional method of estimating the probability of bankruptcy for two standard indices: equity ratio and current liquidity ratio.

\subsection{Disadvantages of Methods}

Despite the simplicity of calculation of indices based on the external reporting and presentation of the results, the current method has some significant drawbacks.

1) Imperfection of the algorithm for calculating indices.

a) In order to own funds ratio really reflects the structure of the sources of working capital, it is necessary to take into account long-term liabilities and deferred income, provisions for liabilities and charges.

b) In order to objectively current ratio reflects the degree of solvency of the organization, it is necessary to take into account the assets actually has adequate liquidity (using data analytical accounting). Today, in addition to individual articles of current assets, these include real estate, long-term investments; short-term liabilities must be adjusted to account for the possible premature claims for repayment of debt, the amounts of trade credit and assets for production with the production cycle over a year.

2) Instantaneous nature of the calculated indices.

Within the reporting period, the values of indices may be materially different from those obtained from calculations according to the balance at the beginning and end of that period.

3) The link between indices.

In the context of a complete or almost complete absence of long-term debt in the majority of organizations, equity ratio, calculated in accordance with traditional methods, in fact, reflects the same level of current liquidity, but a certain number of other means.

4) Extrapolation nature of the coefficient of restitution (loss) of paying capacity.

In its calculating, the transfer of trends in current liquidity ratio in the reporting period to the next one is supposed, but does not take into account the possibility of organizing a variety of measures to restore its solvency. Therefore, the calculation of this ratio shall be implemented based on the prospective financial statements as the quotient of the predicted value of the current ratio between the normative.

5) The inadequacy of the critical values of the indices of the real situation.

The standard value of the current ratio of 2, taken from the world of accounting and analytical practice without real situation in domestic organizations, when most of them continue to work with the significant shortage of working capital. The standard value of the current ratio is uniform for all organizations, and therefore does not take into account sectorial characteristics and type of production of business entities (Tatarkin, 2008). 


\subsection{Method of Detecting Latent stage of the Crisis}

Based on the foregoing, the criteria required to manage crisis management process are defined. These include resource efficiency and effectiveness of the economic sustainability of the organization doing business. Resource efficiency criterion allows using indices developed to identify latent stage of the crisis in the organization.

The method of forecasting and diagnosing crises entrepreneurial activity aimed at maintaining the economic stability of the organization, shall be a part of the program of crisis management organization, which aims to the following:

- Forecasting threat of entry of business organization in the band of crisis development and the loss of economic stability;

- Monitoring of factors external and internal environment functioning of the organization in order to maintain economic stability;

- Early detection of symptoms and the nature of the crisis; determination of the depth of the crisis and their risk for future business development organization and maintain economic stability;

- Identification of key parameters for developing a strategy and tactics of anti-crisis business management and economic sustainability of the organization; localization of the crisis (Broilo, 2010).

In order to recognize the latent crisis, the standard method for calculating the main indices of entrepreneurial activity and economic sustainability of the organization and their comparison with the standards are ineffective just as diagnostic indices integrated probability of a crisis. The need to build a whole system of monitoring and forecasting of crisis for tracking the dynamics of the main indices of economic sustainability of the organization; timely capture signals indicating a possible decrease in the economic stability of the organization; build shortand long-term forecasts of the organization (Pytkina, 2011).

In order to recognize the latent stage of the crisis in the commercial organization, we propose the method of capture weak signals. In this regard, a "weak signal" refers to the threat of primary information about the early signs of imbalance in the economic system of organization, without which and without taking in this regard, the operational organization of preventive measures the best available evidence will go to the loss of economic sustainability.

\subsection{The Technique of Definition of Weak Signals}

For the purposes of recognizing the latent stage of the crisis, we have identified the following groups of key indices are weak signals the onset latency of the crisis:

- Solvency ratios;

- Capital structure factors;

- Indices of effective use of working capital, profitability and financial results;

- Performance indices use a non-current capital and investment activity of the capital.

Efficiency criterion to determine the economic sustainability of the stock of economic stability.

In order to use this criterion, the value of the index level of economic stability is used, which should be compared with the scale of values to get a definite answer about the degree of economic stability. The value of the level index of economic stability equal to one would mean the balance of raising and lowering the level of economic stability factors, in other words - the stability of the organization at a given time.

The effectiveness of implemented measures can be judged by two main criteria: whether overcome the latent crisis and stabilized if economic sustainability of the organization; as the result corresponds spent on the implementation of anti-crisis measures resources (the principle of rationality of the crisis management) (Botkin, 2012). If the measures to overcome the latent crisis proved ineffective, that is, the crisis continues to evolve, or produced insufficient effect of interventions, the organization is forced to return to the starting point of the search for the causes and develop a new strategy to overcome the crisis.

The method of using weak signals provides organizations advance capacity reserve flexibility to eliminate the risk at an early stage. The weaker the signal is caught and identified by the organization, the sooner it fixes the chances and risks of the external and internal environment, the greater her time resource for the adoption and implementation of preventive or neutralizing solutions.

A model of detection of latent crisis is constructed using the method of fuzzy sets, which allows you to enter a linguistic variable with its own set of values, and the relationship of quantitative values of some factor with its 
high-quality linguistic description of the intended functions of the accessory factor to fuzzy sets. Membership function parameters of fuzzy sets are a quantitative measure of cash information uncertainty regarding the analysed parameters, the value of which is described in the linguistic fuzzy form (Cherry, 2011).

\subsection{The Method of Application of the Method of the Latent Stage of the Crisis}

Method for detecting latent stage of the crisis includes the following steps:

- A set of weak signals is formed about the threat of a crisis based on a system of indices that reflect the efficient use of resources of the organization and the state of its solvency. Full set of states of a signal about the threat of a crisis prompted divided into five fuzzy subsets, each subset assigning a numerical value on a scale of assessments (Table 1).

Table 1 . The severity of the signal on the threat of a crisis

\begin{tabular}{llllll}
\hline Linguistic evaluation of signal strength & Very high & High & Moderate & Low & Very low \\
\hline Numerical value of the signal strength & 5 & 4 & 3 & 2 & 1 \\
\hline
\end{tabular}

If no signal, then a score of 0 is assigned.

- Each signal from the group of weak signals about the threat of a crisis has a defined scale of values that uniquely identify the severity of the signal at the present scale.

- Each group of indices and, in general, organization introduces two integral exponent sum signal and the validity signal strengths on the above scale.

- The results of these calculations are determined by:

- The magnitude of the threat of crisis signals (the scope of the threat of the crisis in each direction of economic stability, as well as the organization as a whole). The scale of the threat is characterized by the breadth of the crisis, that is, reflects the number of areas of economic stability of the organization, where possible the development of crisis processes;

- Signal intensity of the threat of a crisis (the signal intensity) for each activity or group of indices that reflect economic sustainability. Signal intensity characterizes the crisis in depth coverage, i.e. the depth of the crisis in the organization.

\subsection{The Method of Determining the Scale and Intensity of the Crisis}

In order to recognize the stage of latent crisis, fuzzy membership function is used, which allows depending on the value of the scale and intensity of threat signals or to diagnose the presence of a hidden crisis in the organization, or a potential crisis and to predict the latent crisis in advance (Ponosova, 2010).

The information base for the analysis of the economic sustainability of the organization in order to detect latent crisis is the accounting and internal reporting.

Given that the value of financial and economic performance may differ significantly for the characteristics of the economic sustainability of the organization in various fields and scope of activities, even within the same industry, it was decided in this method to assess performance based on the study of the dynamics of the deviation indices for the period. For this reason, the index method was used. Each analysed index is an index change of an index of activity or stability of the organization, which is the ratio of the value of this parameter at the beginning and end of the analysed period. In order to assess the indices, there were developed scales of values, which in a particular organization can be changed based on the study of deviations from the values of indices adopted in the organization (Trenenkov, 2002).

It is further proposed to introduce two intermediate index ( $\mathrm{S}$ - integral index of the true conditions of the signal and $\mathrm{F}$ - integral index of the total force signals about the threat of latent crisis), which are calculated by the algorithm (Figure 1). 


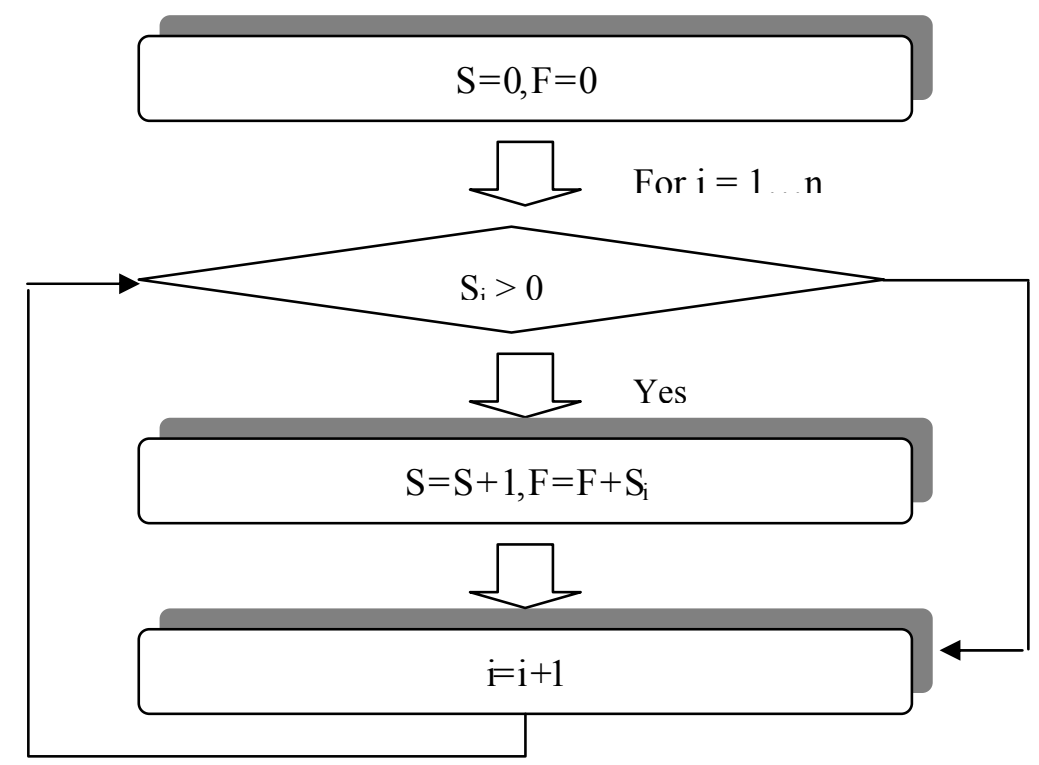

Figure 1. The algorithm for calculating the truth, and the total force signal to a latent crisis

To calculate the magnitude of the threat latent crisis indices for each group or for the whole organization are encouraged to use the following formula:

$$
M=\frac{S}{n} * 100 \%
$$

where $\mathrm{M}$ is the magnitude of the signal of the threat latent crisis; $n$ is the number of analysed parameters in the group or in the whole organization.

The magnitude of the threat of crisis signals a crisis characterized by breadth and gives an idea of the number of areas covered by the latent crisis, or in which the development of the crisis as soon as possible.

The intensity of the threat of crisis is suggested to calculate by the formula:

$$
I^{\prime}=\frac{F}{n * r} * 100 \%
$$

where $I^{\prime}$ is signal intensity of the threat of latent crisis;

$r$ is the dimension of the scale for numerical signal values (in this methodology $r=5$ ) (Pytkina, 2012).

Signal intensity of the threat of a crisis characterized by a crisis in depth coverage and gives an idea of the level of threat of latent crisis.

The scale and intensity of the signals of impending crisis is proposed to estimate the following scale (Table 2).

Table 2. Linguistic evaluation of the extent and intensity of the signals of impending crisis

\begin{tabular}{lll}
\hline $\begin{array}{l}\text { The numerical value } \\
\text { of the index }\end{array}$ & Linguistic evaluation of the index & Forecast \\
\hline Up to $10 \%$ & Very low & Potential crisis \\
$10-20 \%$ & Low & \\
$20-40 \%$ & Medium & Hidden crisis \\
$40-70 \%$ & High & \\
$70-100 \%$ & Very high & \\
\hline
\end{tabular}


Values of greater than $40 \%$ suggest the presence of a latent crisis in the organization and reducing economic sustainability.

When the index values is less than $40 \%$ chance of having a latent crisis is small, the state is characterized as a potential crisis, followed by the possible development of a latent crisis.

\subsection{Definition Signals the Threat of Crisis}

For diagnosis of latent stage of the crisis, organizations of the Republic of Komi were selected, entrepreneurial activity of which in the analysed period was characterized as well, i.e., organization operated in normal mode, and the visible signs of the crisis state of economic stability to them was noted.

With the help of our method and the method described above, there was created a set of "weak signals" of a crisis in the organization, based on the algorithm calculated the intensity and scale of the display signals of a crisis in the organization, and in its absence, the forecast of the probability of loss of economic crisis stability in the near future.

The information base for the analysis of the economic sustainability of the organization in order to detect latent crisis is the accounting and reporting.

I. Solvency indices.

- Assets and liabilities of the organization shall be divided into groups, respectively to the analytical balance:

- Quick assets/liabilities (up to 1 month) $\left(\mathrm{A}_{1} / \Pi_{1}\right)$;

- Assets/liabilities with an average life (1-6 months) $\left(\mathrm{A}_{2} / \Pi_{2}\right)$;

- Illiquid assets/liabilities $\left(\mathrm{A}_{3} / \Pi_{3}\right)$.

This division is due to the need for further comparison of assets and liabilities of each group. In case of failure to use asset/liability within a specified time, the asset may be considered as illiquid and long-term obligations (Bozhko, 2013).

Next, liquidity of deficit or surplus for each group is assessed. At deficiency of liability of each group, any of the stages of the crisis may be diagnosed: if $\mathrm{A}_{1}<\Pi_{1}$, then it can be concluded that there was an acute crisis in the organization; $A_{2}<\Pi_{2}$, then it may be characteristic of latent crisis; situation where $A_{3}<\Pi_{3}$ does not indicate a latent crisis in the organization, though talk about the probability of its occurrence in the future (potential crisis).

Since the deficit of the first group of assets is the outward sign of the presence of the crisis in the organization and is characteristic of the acute phase of the crisis, which cannot be a "weak" signal in this paper is not considered, it is excluded from further analysis.

Thus, at this stage, it is necessary to estimate the ratio of the assets of the second group (the sum of receivables and other current assets) liabilities to the second group (the sum of short-term loans, debt to the founders and other current liabilities) $\mathrm{K}_{1}=\mathrm{A}_{2} / \Pi_{2}$ and distribute its value signal strength on a scale of impending crisis (Table $3)$.

Solvency indices describe the situation with the solvency of the organization in accordance with the amount of its borrowings and timing of any debt repayment to creditors.

- The degree of solvency of the total $\left(\mathrm{K}_{2}\right)$ is determined by dividing the amount borrowed funds (liabilities) organization by the average earnings, which is determined by the formula:

$\mathrm{OP}_{\mathrm{av} . \text { mon. }}=$ Earnings of the organisation / $\mathrm{T}$,

where $\mathrm{OP}_{\mathrm{av} . \text { mon. }}$ is average monthly revenue; $\mathrm{T}$ is the number of months in the reporting period.

$\mathrm{K}_{2}$ index over the debt structure and methods of lending organizations shall be distributed into debt ratios on bank loans and loans to other organizations, fiscal system, and internal debt. Skewed structure of debt towards commodity loans from other organizations, lending hidden due to non-payment of fiscal system of the state and domestic debt payments negatively characterizes the economic activity of the organization and is a possible sign of the emergence of latent crisis in the organization and reduce the economic sustainability (Ponosova, 2010).

- The debt ratio on bank loans and borrowings $\left(\mathrm{K}_{3}\right)$ is calculated as a ratio to the dividing of the sum of long-term liabilities and short-term bank loans and loans on average monthly earnings.

- The debt ratio to other organizations $\left(\mathrm{K}_{4}\right)$ is calculated as a ratio of the dividing of the amount of liabilities to suppliers and contractors, to subsidiaries and associated companies and other creditors and bills payable and 
advances received on average monthly earnings. These obligations are functionally related to liabilities to direct creditors and counterparties.

- Debt ratio to the fiscal system $\left(\mathrm{K}_{5}\right)$ is calculated as a ratio of the dividing of the amount of liabilities to the state budget funds and the budget on the average monthly revenue.

- Coefficient of internal debt $\left(\mathrm{K}_{6}\right)$ is calculated as a ratio of the dividing of the amount payable to personnel, participants (founders) for income payments, deferred income, provisions for future expenses, and other current liabilities in the average monthly revenue.

- The degree of solvency of current liabilities $\left(\mathrm{K}_{7}\right)$ is defined as the ratio of current borrowings organization to the average receipts.

- The coverage ratio of current liabilities current assets $\left(\mathrm{K}_{8}\right)$ is calculated as the ratio of the value of all current assets in the form of inventories, receivables, short-term investments, cash, and other current assets to current liabilities of the organization (Table 3).

Table 3. The system of indexes for solvency indices used to determine the extent and intensity of the signal strength latent stage of the crisis (Davnis, 2012)

\begin{tabular}{|c|c|c|}
\hline Index & Limits & $\begin{array}{l}\text { Numerical value of the } \\
\text { signal }\end{array}$ \\
\hline \multirow{6}{*}{ The index of increase (decrease) for the ratio of $\mathrm{A}_{2}$ to $\Pi_{2}$} & $\mathrm{I}_{1} \geq 1$ & 0 \\
\hline & $0.9 \leq \mathrm{I}_{1}<1$ & 1 \\
\hline & $0.8 \leq \mathrm{I}_{1}<0.9$ & 2 \\
\hline & $0.7 \leq \mathrm{I}_{1}<0.8$ & 3 \\
\hline & $0.5 \leq \mathrm{I}_{1}<0.7$ & 4 \\
\hline & $\mathrm{I}_{1}<0.5$ & 5 \\
\hline \multirow{6}{*}{$\begin{array}{l}\text { The index of increase (decrease) of the total degree of } \\
\text { solvency }\end{array}$} & $\mathrm{I}_{2} \leq 1$ & 0 \\
\hline & $1<\mathrm{I}_{2} \leq 1.1$ & 1 \\
\hline & $1.1<\mathrm{I}_{2} \leq 1.2$ & 2 \\
\hline & $1.2<\mathrm{I}_{2} \leq 1.5$ & 3 \\
\hline & $1.5<\mathrm{I}_{2} \leq 2$ & 4 \\
\hline & $\mathrm{I}_{2}>2$ & 5 \\
\hline \multirow{6}{*}{$\begin{array}{l}\text { The index of increase (decrease) in the debt ratio on bank } \\
\text { loans and borrowings }\end{array}$} & $\mathrm{I}_{3} \leq 1$ & 0 \\
\hline & $1<\mathrm{I}_{3} \leq 1.1$ & 1 \\
\hline & $1.1<\mathrm{I}_{3} \leq 1.2$ & 2 \\
\hline & $1.2<\mathrm{I}_{3} \leq 1.5$ & 3 \\
\hline & $1.5<\mathrm{I}_{3} \leq 2$ & 4 \\
\hline & $\mathrm{I}_{3}>2$ & 5 \\
\hline \multirow{6}{*}{$\begin{array}{l}\text { The index of increase (decrease) in the debt ratio to other } \\
\text { organizations }\end{array}$} & $\mathrm{I}_{4} \leq 1$ & 0 \\
\hline & $1<\mathrm{I}_{4} \leq 1.1$ & 1 \\
\hline & $1.1<\mathrm{I}_{4} \leq 1.2$ & 2 \\
\hline & $1.2<\mathrm{I}_{4} \leq 1.5$ & 3 \\
\hline & $1.5<\mathrm{I}_{4} \leq 2$ & 4 \\
\hline & $\mathrm{I}_{4}>2$ & 5 \\
\hline \multirow{2}{*}{$\begin{array}{l}\text { The index of increase (decrease) in the debt ratio to the } \\
\text { fiscal system }\end{array}$} & $\mathrm{I}_{5} \leq 1$ & 0 \\
\hline & $1<\mathrm{I}_{5} \leq 1.1$ & 1 \\
\hline
\end{tabular}




\begin{tabular}{|c|c|c|}
\hline Index & Limits & $\begin{array}{l}\text { Numerical value of the } \\
\text { signal }\end{array}$ \\
\hline & $1.1<\mathrm{I}_{5} \leq 1.2$ & 2 \\
\hline & $1.2<\mathrm{I}_{5} \leq 1.5$ & 3 \\
\hline & $1.5<\mathrm{I}_{5} \leq 2$ & 4 \\
\hline & $\mathrm{I}_{5}>2$ & 5 \\
\hline \multirow{6}{*}{ The index of increase (decrease) of the internal debt ratio } & $\mathrm{I}_{6} \leq 1$ & 0 \\
\hline & $1<\mathrm{I}_{6} \leq 1.1$ & 1 \\
\hline & $1.1<\mathrm{I}_{6} \leq 1.2$ & 2 \\
\hline & $1.2<\mathrm{I}_{6} \leq 1.5$ & 3 \\
\hline & $1.5<\mathrm{I}_{6} \leq 2$ & 4 \\
\hline & $\mathrm{I}_{6}>2$ & 5 \\
\hline \multirow{6}{*}{$\begin{array}{l}\text { The index of increase (decrease) of the degree of } \\
\text { solvency for the current } \\
\text { liabilities }\end{array}$} & $\mathrm{I}_{7} \leq 1$ & 0 \\
\hline & $1<\mathrm{I}_{7} \leq 1.1$ & 1 \\
\hline & $1.1<\mathrm{I}_{7} \leq 1.2$ & 2 \\
\hline & $1.2<\mathrm{I}_{7} \leq 1.5$ & 3 \\
\hline & $1.5<\mathrm{I}_{7} \leq 2$ & 4 \\
\hline & $\mathrm{I}_{7}>2$ & 5 \\
\hline \multirow{6}{*}{$\begin{array}{l}\text { The index of increase (decrease) for paying for current } \\
\text { liabilities with current assets }\end{array}$} & $\mathrm{I}_{8} \geq 1$ & 0 \\
\hline & $0.9 \leq \mathrm{I}_{8}<1$ & 1 \\
\hline & $0.8 \leq \mathrm{I}_{8}<0.9$ & 2 \\
\hline & $0.7 \leq \mathrm{I}_{8}<0.8$ & 3 \\
\hline & $0.5 \leq \mathrm{I}_{8}<0.7$ & 4 \\
\hline & $\mathrm{I}_{8}<0.5$ & 5 \\
\hline
\end{tabular}

\section{Capital structure factors.}

The second group of indices, analysed in the framework of this method, includes the indices of capital structure, which reflects the ratio of debt to equity in the financing of the organization, i.e., characterize the degree of financial independence from creditors. To construct recognition techniques latent stage of the crisis, the following indices were highlighted.

- The share of equity in working capital or own funds ratio $\left(\mathrm{K}_{9}\right)$, calculated as the ratio of own funds in circulation to the entire value of current assets. The index shows the gearing ratio of current assets and determines the degree of security of the organization's own working capital necessary for its financial stability.

- Autonomy ratio $\left(\mathrm{K}_{10}\right)$, or financial independence, which is calculated by dividing shareholders' equity for assets of the organization and determines the fraction of the organization's assets, which are covered by equity (provided by own sources). The remaining share of assets covered by borrowings. The index is the ratio of debt to equity organization.

- The ratio of total liabilities to total assets $\left(\mathrm{K}_{11}\right)$ is an index of the share of the assets, which is funded by long-term and short-term loans.

- The ratio of long-term debt to total assets $\left(\mathrm{K}_{12}\right)$ shows the share of assets financed by long-term loans.

- The ratio of total debt to equity $\left(\mathrm{K}_{13}\right)$ is the ratio of loan and equity financing.

- The ratio of long-term liabilities to non-current assets $\left(\mathrm{K}_{14}\right)$ shows the proportion of fixed assets financed by long-term loans.

Table 4 presents the intervals of index values for indices of capital structure needed to determine the extent and intensity of the threat of covert signal crisis. 
Table 4. The system of indexes for capital structure indices used to determine the extent and intensity of the signal strength latent stage of the crisis (Davnis, 2012)

\begin{tabular}{|c|c|c|}
\hline Index & Limits & $\begin{array}{l}\text { Numerical value } \\
\text { of the signal }\end{array}$ \\
\hline \multirow{6}{*}{ The index of increase (decrease) of equity ratio } & $\mathrm{I}_{9} \geq 1$ & 0 \\
\hline & $0.9 \leq \mathrm{I}_{9}<1$ & 1 \\
\hline & $0.8 \leq \mathrm{I}_{9}<0.9$ & 2 \\
\hline & $0.7 \leq \mathrm{I}_{9}<0.8$ & 3 \\
\hline & $0.5 \leq \mathrm{I}_{9}<0.7$ & 4 \\
\hline & $\mathrm{I}_{9}<0.5$ & 5 \\
\hline \multirow{6}{*}{ The index of increase (decrease) of autonomy ratio } & $\mathrm{I}_{10} \geq 1$ & 0 \\
\hline & $0.9 \leq \mathrm{I}_{10}<1$ & 1 \\
\hline & $0.8 \leq \mathrm{I}_{10}<0.9$ & 2 \\
\hline & $0.7 \leq \mathrm{I}_{10}<0.8$ & 3 \\
\hline & $0.5 \leq \mathrm{I}_{10}<0.7$ & 4 \\
\hline & $\mathrm{I}_{10}<0.5$ & 5 \\
\hline \multirow{6}{*}{$\begin{array}{l}\text { The index of increase (decrease) of ratio of total } \\
\text { liabilities to total assets }\end{array}$} & $\mathrm{I}_{11} \leq 1$ & 0 \\
\hline & $1<\mathrm{I}_{11} \leq 1.1$ & 1 \\
\hline & $1.1<\mathrm{I}_{11} \leq 1.2$ & 2 \\
\hline & $1.2<\mathrm{I}_{11} \leq 1.5$ & 3 \\
\hline & $1.5<\mathrm{I}_{11} \leq 2$ & 4 \\
\hline & $\mathrm{I}_{11}>2$ & 5 \\
\hline \multirow{6}{*}{$\begin{array}{l}\text { The index of increase (decrease) of ratio of long-term } \\
\text { liabilities to assets }\end{array}$} & $\mathrm{I}_{12} \leq 1$ & 0 \\
\hline & $1<\mathrm{I}_{12} \leq 1.1$ & 1 \\
\hline & $1.1<\mathrm{I}_{12} \leq 1.2$ & 2 \\
\hline & $1.2<\mathrm{I}_{12} \leq 1.5$ & 3 \\
\hline & $1.5<\mathrm{I}_{12} \leq 2$ & 4 \\
\hline & $\mathrm{I}_{12}>2$ & 5 \\
\hline \multirow{6}{*}{$\begin{array}{l}\text { The index of increase (decrease) of ratio of total debt to } \\
\text { equity }\end{array}$} & $\mathrm{I}_{13} \leq 1$ & 0 \\
\hline & $1<\mathrm{I}_{13} \leq 1.1$ & 1 \\
\hline & $1.1<\mathrm{I}_{13} \leq 1.2$ & 2 \\
\hline & $1.2<\mathrm{I}_{13} \leq 1.5$ & 3 \\
\hline & $1.5<\mathrm{I}_{13} \leq 2$ & 4 \\
\hline & $\mathrm{I}_{13}>2$ & 5 \\
\hline \multirow{6}{*}{$\begin{array}{l}\text { The index of increase (decrease) of long-term liabilities } \\
\text { to non-current assets }\end{array}$} & $\mathrm{I}_{14} \leq 1$ & 0 \\
\hline & $1<\mathrm{I}_{14} \leq 1.1$ & 1 \\
\hline & $1.1<\mathrm{I}_{14} \leq 1.2$ & 2 \\
\hline & $1.2<\mathrm{I}_{14} \leq 1.5$ & 3 \\
\hline & $1.5<\mathrm{I}_{14} \leq 2$ & 4 \\
\hline & $\mathrm{I}_{14}>2$ & 5 \\
\hline
\end{tabular}


III. Indices of effective use of working capital, profitability, and financial results. They evaluate the velocity of circulation of money invested in current assets. In this method, they are complemented with coefficients of working capital in production and in the calculations, the values that characterize the structure of the current assets of the organization:

- Ratio of current assets $\left(\mathrm{K}_{15}\right)$ is calculated by dividing current assets by the average organization's revenue and characterizes the amount of current assets, expressed as a monthly average income of the organization, as well as their turnover. This index measures the velocity of circulation of money invested in current assets.

- The coefficient of working capital in production $\left(\mathrm{K}_{16}\right)$ is calculated as the ratio of the value of working capital in the production to the average receipts. Current assets are defined as in the production of money in stocks including VAT minus the cost of goods shipped. Coefficient characterizes the turnover of inventory organization. Its values are determined by industry-specific production, characterize the efficiency of production and marketing activities.

- Factor of working capital $\left(\mathrm{K}_{17}\right)$ in the calculation determines the speed determines the velocity of circulating assets of the organization is not involved in direct production. It characterizes the first medium term payments for goods shipped but not yet paid for the product; determines the medium terms, which are derived from the production process current assets that are in the calculations. In addition, it can give an idea on how much liquid is the products manufactured by the organization, and how efficiently organized its relationships with customers, characterizes the probability of bad and doubtful debts and write-offs as a result of shortfalls in payments, i.e. the degree of commercial risk (Arzyakova, 2011).

- Return on working capital $\left(\mathrm{K}_{18}\right)$ reflects the efficiency of working capital. It determines the amount of profit per rouble, invested in current assets.

- Return on sales $\left(\mathrm{K}_{19}\right)$ represents the ratio of profit from sales of products and income received in the reporting period.

- The average monthly output per worker $\left(\mathrm{K}_{20}\right)$ determines the efficiency of the organization of labour and labour productivity, as well as describes the financial resources for entrepreneurial activities and commitments given to one employee of the organization.

Table 5. The system of indexes for efficient use of working capital, profitability, and financial results used to determine the extent and intensity of the signal strength latent stage of the crisis (Davnis, 2012)

\begin{tabular}{|c|c|c|}
\hline Index & Limits & $\begin{array}{l}\text { Numerical } \\
\text { value of the } \\
\text { signal }\end{array}$ \\
\hline \multirow{6}{*}{$\begin{array}{l}\text { The index of increase (decrease) of current assets } \\
\text { coverage ratio }\end{array}$} & $\mathrm{I}_{15} \geq 1$ & 0 \\
\hline & $0.9 \leq \mathrm{I}_{15}<1$ & 1 \\
\hline & $0.8 \leq \mathrm{I}_{15}<0.9$ & 2 \\
\hline & $0.7 \leq \mathrm{I}_{15}<0.8$ & 3 \\
\hline & $0.5 \leq \mathrm{I}_{15}<0.7$ & 4 \\
\hline & $\mathrm{I}_{15}<0.5$ & 5 \\
\hline \multirow{6}{*}{$\begin{array}{l}\text { The index of increase (decrease) of ratio of current assets in } \\
\text { production }\end{array}$} & $\mathrm{I}_{16} \geq 1$ & 0 \\
\hline & $0.9 \leq \mathrm{I}_{16}<1$ & 1 \\
\hline & $0.8 \leq \mathrm{I}_{16}<0.9$ & 2 \\
\hline & $0.7 \leq \mathrm{I}_{16}<0.8$ & 3 \\
\hline & $0.5 \leq \mathrm{I}_{16}<0.7$ & 4 \\
\hline & $\mathrm{I}_{16}<0.5$ & 5 \\
\hline \multirow{3}{*}{$\begin{array}{l}\text { The index of increase (decrease) of ratio of current assets in } \\
\text { calculation }\end{array}$} & $\mathrm{I}_{17} \geq 1$ & 0 \\
\hline & $0.9 \leq \mathrm{I}_{17}<1$ & 1 \\
\hline & $0.8 \leq \mathrm{I}_{17}<0.9$ & 2 \\
\hline
\end{tabular}




\begin{tabular}{|c|c|c|}
\hline & $0.7 \leq \mathrm{I}_{17}<0.8$ & 3 \\
\hline & $0.5 \leq \mathrm{I}_{17}<0.7$ & 4 \\
\hline & $\mathrm{I}_{17}<0.5$ & 5 \\
\hline \multirow{6}{*}{ The index of increase (decrease) in working capital profitability } & $\mathrm{I}_{18} \geq 1$ & 0 \\
\hline & $0.9 \leq \mathrm{I}_{18}<1$ & 1 \\
\hline & $0.8 \leq \mathrm{I}_{18}<0.9$ & 2 \\
\hline & $0.7 \leq \mathrm{I}_{18}<0.8$ & 3 \\
\hline & $0.5 \leq \mathrm{I}_{18}<0.7$ & 4 \\
\hline & $\mathrm{I}_{18}<0.5$ & 5 \\
\hline \multirow{6}{*}{ The index of increase (decrease) of profitability of sales } & $\mathrm{I}_{18} \geq 1$ & 0 \\
\hline & $0.9 \leq \mathrm{I}_{18}<1$ & 1 \\
\hline & $0.8 \leq \mathrm{I}_{18}<0.9$ & 2 \\
\hline & $0.7 \leq \mathrm{I}_{18}<0.8$ & 3 \\
\hline & $0.5 \leq \mathrm{I}_{18}<0.7$ & 4 \\
\hline & $\mathrm{I}_{18}<0.5$ & 5 \\
\hline \multirow{6}{*}{ The index of increase (decrease) of the average output per worker } & $\mathrm{I}_{20} \geq 1$ & 0 \\
\hline & $0.9 \leq \mathrm{I}_{20}<1$ & 1 \\
\hline & $0.8 \leq \mathrm{I}_{20}<0.9$ & 2 \\
\hline & $0.7 \leq \mathrm{I}_{20}<0.8$ & 3 \\
\hline & $0.5 \leq \mathrm{I}_{20}<0.7$ & 4 \\
\hline & $\mathrm{I}_{20}<0.5$ & 5 \\
\hline
\end{tabular}

IV. The last group of indices included in this method covers the effective use of indices and non-current capital investment activity characterizing the efficiency of the fixed assets of the organization and determine how the total available assets (machinery, equipment, buildings, vehicles) corresponds to the size of the business organization. We offer the following indices.

- The effectiveness of the non-current capital, or capital productivity $\left(\mathrm{K}_{21}\right)$, which is defined as the ratio of average monthly revenue to the value of non-current equity and characterizes the efficiency of the fixed assets of the organization. Less than the industry average, the value of this index characterizes insufficient utilization of equipment in the event that the organization in the period under review did not acquire expensive new plant and equipment. While the very high value of this index can testify to a full load of equipment and lack of reserves, and to a significant degree of physical and moral deterioration of outdated production equipment.

- Investment activity coefficient $\left(\mathrm{K}_{22}\right)$, which characterizes the investment activity and determines the amount of funds allocated for the organization of the modification and improvement of the property, as well as investments in other companies. Strong deviations of this index in either direction could indicate poor development strategy of the organization or lack of control over the activities of the organization's leadership management.

- Net profit ratio of non-current assets $\left(\mathrm{K}_{23}\right)$, showing the ability of the organization to provide a sufficient amount of profit in relation to fixed assets.

- Return on investment ratio $\left(\mathrm{K}_{24}\right)$, showing how much money units required for the organization of one unit profit. This index is one of the most important indices of competitiveness.

- Table 6 shows the ranges of indexes of indices effective use of non-current capital and investment activity of the organization. 
Table 6. The system of indexes for efficient use of capital and non-current investment activity used to determine the extent and intensity of the signal strength latent stage of the crisis (Davnis, 2012)

\begin{tabular}{lll}
\hline Index & Limits & $\begin{array}{l}\text { Numerical value } \\
\text { of the signal }\end{array}$ \\
\hline
\end{tabular}

The index of increase (decrease) in capital productivity

\begin{tabular}{|c|c|}
\hline $\mathrm{I}_{21} \geq 1$ & 0 \\
\hline $0.9 \leq \mathrm{I}_{21}<1$ & 1 \\
\hline $0.8 \leq \mathrm{I}_{21}<0.9$ & 2 \\
\hline $0.7 \leq \mathrm{I}_{21}<0.8$ & 3 \\
\hline $0.5 \leq \mathrm{I}_{21}<0.7$ & 4 \\
\hline $\mathrm{I}_{21}<0.5$ & 5 \\
\hline $\mathrm{I}_{22} \geq 1$ & 0 \\
\hline $0.9 \leq \mathrm{I}_{22}<1$ & 1 \\
\hline $0.8 \leq \mathrm{I}_{22}<0.9$ & 2 \\
\hline $0.7 \leq \mathrm{I}_{22}<0.8$ & 3 \\
\hline $0.5 \leq \mathrm{I}_{22}<0.7$ & 4 \\
\hline $\mathrm{I}_{22}<0.5$ & 5 \\
\hline$I_{23} \geq 1$ & 0 \\
\hline $0.9 \leq \mathrm{I}_{23}<1$ & 1 \\
\hline $0.8 \leq \mathrm{I}_{23}<0.9$ & 2 \\
\hline $0.7 \leq \mathrm{I}_{23}<0.8$ & 3 \\
\hline $0.5 \leq \mathrm{I}_{23}<0.7$ & 4 \\
\hline $\mathrm{I}_{23}<0.5$ & 5 \\
\hline $\mathrm{I}_{24} \geq 1$ & 0 \\
\hline $0.9 \leq \mathrm{I}_{24}<1$ & 1 \\
\hline $0.8 \leq \mathrm{I}_{24}<0.9$ & 2 \\
\hline $0.7 \leq \mathrm{I}_{24}<0.8$ & 3 \\
\hline $0.5 \leq \mathrm{I}_{24}<0.7$ & 4 \\
\hline $\mathrm{I}_{24}<0.5$ & 5 \\
\hline
\end{tabular}

\section{Results}

After finding the index indices and their behaviour in the studied period, it is necessary to calculate the values of milestones - the true conditions of the counter (S) and the total force signal counter the threat of latent crisis (F) for the analysed organizations using the cited earlier algorithm (Figure 2).

The index ranges used in the calculation allow setting each value belonging to the value of the scale of a fuzzy set.

Values of true signals and the total force of signals confirming the existence of a latent crisis in the organizations studied are shown in Table 7. 
Table 7. The value of the number of true conditions for the existence of latent stage of the crisis and the total force of the signals

\begin{tabular}{|c|c|c|c|c|c|c|}
\hline \multirow{2}{*}{$\begin{array}{l}\text { Signal } \\
\text { counter }\end{array}$} & \multicolumn{2}{|c|}{ Syktyvkarkhleb, OOO } & \multicolumn{2}{|c|}{ Komiteks, OJSC } & \multicolumn{2}{|c|}{$\begin{array}{l}\text { Pechorsk Bread and } \\
\text { Complex, OJSC }\end{array}$} \\
\hline & 2012 & 2013 & 2012 & 2013 & 2012 & 2013 \\
\hline \multicolumn{7}{|c|}{ Solvency ratio } \\
\hline$\overline{\mathrm{S}}$ & 2 & 2 & 2 & 4 & 0 & 1 \\
\hline $\bar{F}$ & 4 & 6 & 9 & 10 & 0 & 4 \\
\hline \multicolumn{7}{|c|}{ Capital structure factors } \\
\hline$\overline{\mathrm{S}}$ & 1 & 0 & 3 & 2 & 2 & 0 \\
\hline$\overline{\mathrm{F}}$ & 5 & 0 & 9 & 9 & 6 & 0 \\
\hline
\end{tabular}

Indices of effective use of working capital, profitability and financial results

\begin{tabular}{lllllll}
\hline $\mathrm{S}$ & 3 & 3 & 5 & 2 & 3 & 4 \\
\hline $\mathrm{F}$ & 9 & 4 & 25 & 4 & 15 & 9 \\
\hline
\end{tabular}

Performance indices use a non-current capital and investment activity

\begin{tabular}{lllllll}
\hline $\mathrm{S}$ & 2 & 2 & 2 & 0 & 2 & 2 \\
\hline $\mathrm{F}$ & 9 & 8 & 10 & 0 & 10 & 2 \\
\hline \multicolumn{2}{l}{ Total values of S and F } & & & & 7 & 7 \\
\hline $\mathrm{S}$ & 8 & 7 & 12 & 8 & 31 & 15 \\
\hline $\mathrm{F}$ & 27 & 18 & 53 & 23 & & \\
\hline
\end{tabular}

The calculated values of the scale M (Formula 1) and the intensity I (Formula 2) signals on the threat of latent crisis for commercial organizations Syktyvkarkhleb, OOO, Komiteks, OJSC, Pechorsk Bread and Pasta Complex, OJSC are presented in Table 8.

Table 8 . The value of the scale and intensity of the signals of the threat of latent crisis for the period 2012-2013

\begin{tabular}{|c|c|c|c|c|c|c|c|}
\hline \multirow{2}{*}{$\begin{array}{l}\text { Signals } \\
\text { meaning }\end{array}$} & \multicolumn{2}{|c|}{ Syktyvkarkhleb, OOO } & \multicolumn{2}{|c|}{ Komiteks, OJSC } & \multicolumn{3}{|c|}{$\begin{array}{l}\text { Pechorsk Bread and Pasta } \\
\text { Complex, OJSC }\end{array}$} \\
\hline & 2012 & 2013 & 2012 & 2013 & 2012 & 2013 & \\
\hline \multicolumn{8}{|c|}{$\overline{\text { Solvency ratio }}$} \\
\hline$\overline{\mathrm{M}}$ & $25 \%$ & $25 \%$ & $25 \%$ & $50 \%$ & $0 \%$ & $13 \%$ & \\
\hline I & $10 \%$ & $15 \%$ & $23 \%$ & $25 \%$ & $0 \%$ & $10 \%$ & \\
\hline \multicolumn{8}{|c|}{ Capital structure factors } \\
\hline $\bar{M}$ & $13 \%$ & $0 \%$ & $38 \%$ & $25 \%$ & $25 \%$ & $0 \%$ & \\
\hline $\mathrm{I}$ & $13 \%$ & $0 \%$ & $23 \%$ & $23 \%$ & $15 \%$ & $0 \%$ & \\
\hline \multicolumn{8}{|c|}{ Indices of effective use of working capital, profitability and financial results } \\
\hline$\overline{\mathrm{M}}$ & $38 \%$ & $38 \%$ & $63 \%$ & $25 \%$ & $38 \%$ & $50 \%$ & \\
\hline $\mathrm{I}$ & $23 \%$ & $10 \%$ & $63 \%$ & $10 \%$ & $38 \%$ & $23 \%$ & \\
\hline
\end{tabular}


Signals

meaning
Komiteks, OJSC
Pechorsk Bread and Pasta Complex, OJSC

\begin{tabular}{llllll}
\hline 2012 & 2013 & 2012 & 2013 & 2012 & 2013
\end{tabular}

Performance indices use a non-current capital and investment activity

\begin{tabular}{lllllll}
\hline $\mathrm{M}$ & $25 \%$ & $25 \%$ & $25 \%$ & $0 \%$ & $25 \%$ & $25 \%$ \\
\hline $\mathrm{I}$ & $23 \%$ & $20 \%$ & $25 \%$ & $0 \%$ & $25 \%$ & $5 \%$ \\
\hline
\end{tabular}

Total values for M and I

\begin{tabular}{lllllll}
\hline $\mathrm{M}$ & $100 \%$ & $88 \%$ & $150 \%$ & $100 \%$ & $88 \%$ & $88 \%$ \\
\hline $\mathrm{I}$ & $68 \%$ & $45 \%$ & $133 \%$ & $58 \%$ & $78 \%$ & $38 \%$ \\
\hline
\end{tabular}

The values of the scale and the latent threat of crisis as calculated by groups of indices that reflect the economic stability of organizations and on the organization as a whole. The total values of the indices give only a general picture of the presence of latent crisis in the whole organization and allow us to represent graphically the situation, as it is done below. The scale and intensity of the signals of the threat of the crisis are, respectively, the breadth and depth of the latent crisis (Figure 2).

Economic sustainability study of organizations in 2012-2013 is within acceptable limits, but still the organizations are in crisis, which could adversely affect the business. It is safe to say that not only talk about the solvency indices of sustainable trends in the organizations. Calculations showed that the assessment of the economic stability must be comprehensive, in terms of solvency, the efficient use of working capital and non-current, profitability and financial results, production, marketing and economic components (Shulgin, 2012).

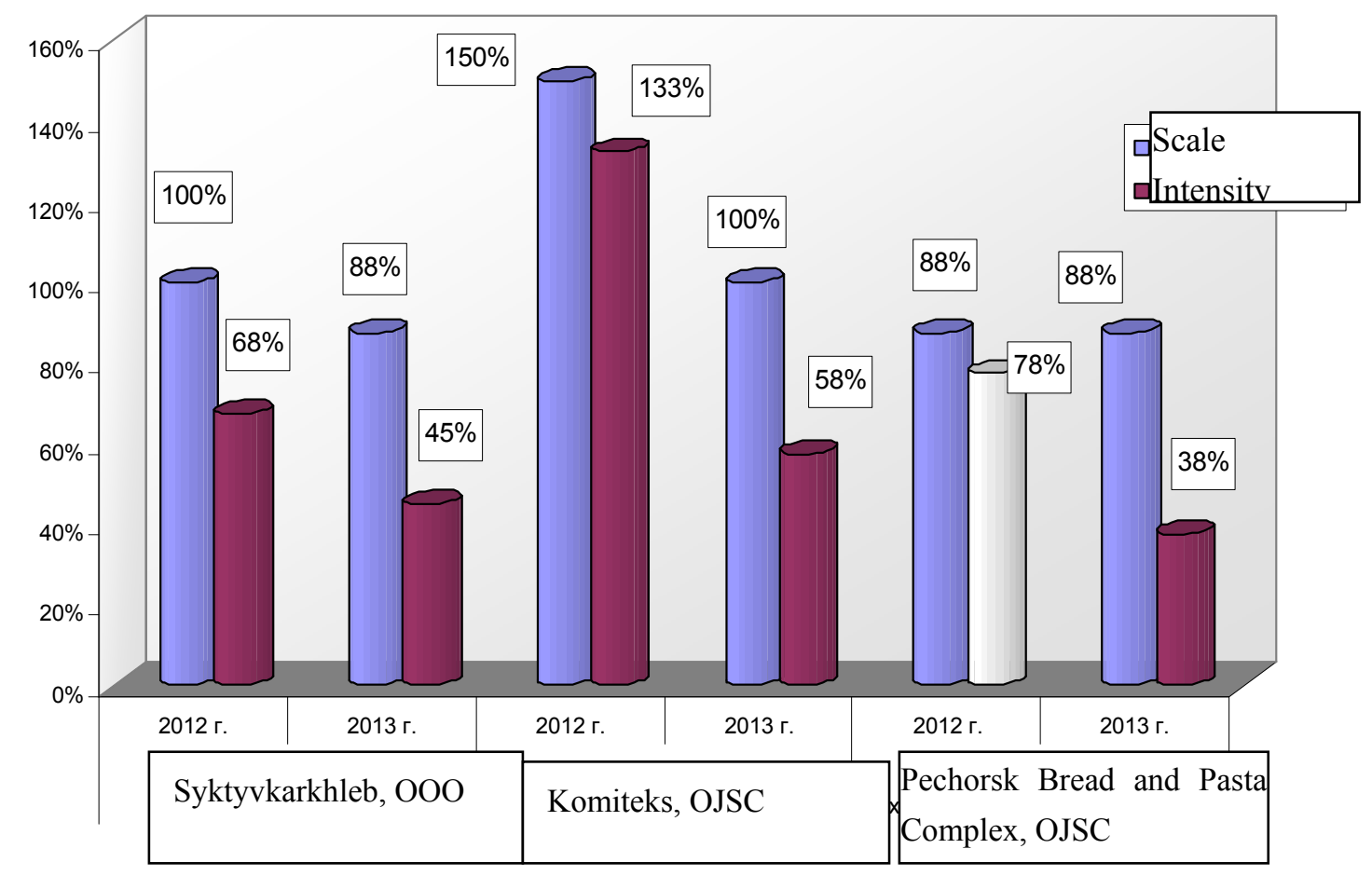

Figure 2. The scale and intensity of the latent crisis in the studied organizations

\section{Discussion and Conclusions}

The analysis showed that the differences in the approaches to the management of sustainable development of the 
commercial organization are due mainly to different understanding of its essence, which is a consequence of the imperfection of the existing conceptual apparatus (Shulgin, 2012). The performed analysis also confirmed that sustainable development of a commercial organization should ensure coherent implementation of the objectives-economic and social.

The surveys depending on which group the greatest indices recorded signals of a crisis, examples of stabilization measures may include the following steps.

- Upon detection of the symptoms of latent crisis for the group solvency ratios: restoring the liquidity of assets; restoration of efficient ratio of assets and liabilities with an average term of realization; optimization of the credit policy of the organization; ordering payments system organization with direct lenders, suppliers of materials, equipment, customers, staff; ordering and control over the order of settlements with the fiscal system; deleveraging in relation to own funds to the optimum level. On a group of indices of capital structure: increasing the availability of internal funds of the organization; optimization of factors of autonomy and financial dependence; improvement or introduction of new progressive forms and processes for managing capital; decline in the share of receivables in the assets of organization, including through the optimization of settlements with creditors and enhance the efficiency policy of the organization in this area, control over the repayment of funds.

- On a group of indices of effective working capital: increase in the velocity of circulation of money invested in current assets; increase in turnover of inventories of the organization; improving the system of cost accounting; optimization of production planning; decline in the share of production costs per unit of output; improving the quality and competitiveness of products; improving the efficiency of marketing; reduction of terms of payment for sold, but not paid for the products; increasing the liquidity of the products manufactured by the organization; reduction in the degree of commercial risk; more efficient use, working capital turnover; increasing the share of profits from product sales in the revenue of the organization; numerical optimization of the structure and related job requirements of employees of the organization; more efficient use of labour organization and the level of productivity.

- The fourth group of indices covers the effective use of non-current capital and investment activity: alignment of the total available assets (machinery, equipment, buildings, vehicles, resources invested in the improvement of the property) to the size of the business organization; more efficient use of the fixed assets of the organization; decrease in the proportion of outdated production equipment; increasing investment activity by establishing or strengthening the organization's policy with regard to investments aimed at modification and improvement of the property, as well as investments in other companies.

These activities can be supplemented by other measures aimed at stabilizing the economic stability and recovery from the crisis, but must be kept in the system. This system is designed to ensure prompt restoration of economic stability, the output from the latent crisis and prevent its further development and the transition to the stage of acute crisis, restore the normal business activities of the organization.

The results of the calculations and analysis concluded that there is latent progressive crisis at Komiteks, OJSC, which subsequently has been developed; Syktyvkarkhleb, OOO faces with developing the latent crisis and Pechorsk Bread and Pasta Complex, OJSC faces with latent emerging crisis. Accordingly, activities may include: more efficient use of fixed assets, such as higher capital productivity; revision of the policy of the organization in the modernization of the equipment and investment activity. Under conditions of acute and chronic crisis, there shall be used more drastic measures to mitigate and eliminate, some of which can be applied in the case of detection of latent crisis. Such activities include:

- Innovative reform, which is one of the elements of advanced crisis management. Measures of innovative reforms include measures for the release of funds for the improvement of the production: marketing research, enhancing competitiveness, increasing the quality and variety of products.

- Modernization or unprofitable or marginally profitable stop minor productions, and if necessary re-production activities in the event of non-competitiveness of its products.

- Claiming receivables and possible concessions of the claims under it, which will free up working capital of the organization. However, it must be remembered that such assignment is made at a discount, which in some cases can be very high.

- Implementation of excessive stocks of inventory. This will allow the organization to release part of the working capital, increase the liquidity of their assets, and send the released funds for the implementation of anti-crisis programs and projects. 
- Implementation of commercial applications can also be used in the organization for the release of funds, reduce costs and increase efficiency in the use of fixed assets.

Once developed plan of anti-crisis measures are implemented, there shall be carried out an evaluation of the effectiveness of such a plan. The effectiveness of implemented measures can be judged by two main criteria: the level of achieving the goal of anti-crisis strategy — whether overcome the latent crisis and stabilized if economic sustainability of the organization; as the result corresponds spent on the implementation of anti-crisis measures resources (the principle of rationality of the crisis management). If the measures to overcome the latent crisis proved to be ineffective, the organization is forced to return to the starting point of the search for the causes and develop a new strategy to overcome the crisis.

Using the methodological principles, methods and techniques of crisis management organization of economic stability in crisis processes in a number of organizations doing business led to the conclusion that the methodology presented in this paper can be used as a tool to ensure the economic stability of the organizations business sectors.

\section{References}

Anokhin, S. N. (2000). Technique of modelling of economic stability of the industrial enterprises in modern conditions. Saratov: Edition of State technical University of Saratov.

Arzyakova, I. V. (2011). Diagnostics of deliberate bankruptcy on the basis of the analysis of acts with the raised risk. Effective crisis management, 62-67.

Botkin, O. I., \& Grebenkin, A. V. (2012). Organization of crisis management by the industrial enterprises (p. 162). Izhevsk: Udmurtskiy branch of the Russian Academy of Sciences, Institute of Economics.

Broilo, E. V. (2010). Regional strategy of management of the crisis organizations. In Monography (p. 226). Moscow.

Bozhko, V. P., Balychev, S. U., \& Batkovsky, A. M. (2013). Management of financial stability of enterprises. Economy, statistics and informatics, 36-41.

Booth S. (2009). Crisis Management Strategy. Competition and Change in Modern Enterprises (p. 313). London: "Routiedge".

Chereshnev V. A., Tatarkin, A. I., \& Glazyev S. U. (2011). Forecasting of social and economic development of the region (p. 1104). Ekaterinburg: Institute of economy of the Russian Academy of Sciences.

Davnis, V. V. (2012). Ekonomichesky the analysis of financial stability of the organization with use of expected models. Modern economy: Problems and decisions, 33-44.

Irvine, R. B. (2003). What's a crisis, anyway? Communication World, 36-40.

Ivanov, G. P. (2000). Crisis management: from bankruptcy-To financial improvement (p. 320). Moscow: UNITY.

Fink, S. (2009). Crisis management. Planning for the Inevi-table. Chicago: “AMACOM American Management Association".

Kaplan, R. C., \& Norton, D. (2008). The balanced system of indices. In From strategy to action (p. 120). Moscow: Joint-Stock Company "Olympus-business".

Klimenkov, G. V. (2005). Financial balancing of the enterprise in competitive (p. 23). Ekaterinburg: Institute of economy of the Russian Academy of Sciences.

Ponosova, E. V. (2010). Key provisions of the theory of crisis and its applied appendix in business management (p. 208). Ekaterinburg: Institute of economy of the Russian Academy of Sciences.

Pytkin, A. N., \& Ponosova, E. V. (2012). Economical mechanism in system of crisis management of enterprise (p. 129). Ekaterinburg: Institute of economy of the Russian Academy of Sciences.

Pytkin, A. N., \& Ponosova, E. V. (2011). Factors of crisis management by the industrial enterprise (p. 186). Ekaterinburg: Institute of economy of the Russian Academy of Sciences.

Persky, U. K. (2010). Management of innovative development of social and economic systems (p. 519). Ekaterinburg: Russian Academy of Sciences.

Romanova, O. A., Tatarkin, A. I., Chechenova, R. I., \& Makarova, I. V. (2012). Regional industrial policy: from macroeconomic conditions of formation to new institutes of development (p. 359). Moscow: Publishing 
Academy of Sciences, Institute of economy of the Russian Academy of Sciences.

Shulgina, L. V., \& Glekov, P. A. (2012). Printsip of a sustainable development of the enterprises in the conditions of financial crisis: Specification of concepts. FES: Finance. Economy. Strategy, 5-9.

Tatarkin, A. I. (2012). Problems of a sustainable development of social and economic systems (p. 554). Moscow: Institute of economy of the Russian Academy of Sciences.

Tatarkin, A. I., \& Yurganova, L. A. (2008). Theoretical and methodological approaches to research of the regional competition. Region Economy, 4-22.

Trenenkov, E. M., \& Dvedenidova, S. A. (2002). Diagnostics in crisis management. Management in Russia and abroad, 8-14.

The north as object of complex regional researches. (2009). The monography (p. 43). Syktyvkar: Publishing house of Komi, Institute of economy of the Russian Academy of Sciences.

\section{Copyrights}

Copyright for this article is retained by the author(s), with first publication rights granted to the journal.

This is an open-access article distributed under the terms and conditions of the Creative Commons Attribution license (http://creativecommons.org/licenses/by/3.0/). 